\title{
40. Adolpho Lutz, uma Vida Dedicada à Ciência
}

\author{
Joffre Marcondes de Rezende
}

\section{SciELO Books / SciELO Livros / SciELO Libros}

REZENDE, J. M. Adolpho Lutz, uma Vida Dedicada à Ciência. In: À sombra do plátano: crônicas de história da medicina [online]. São Paulo: Editora Unifesp, 2009, pp. 349-353. História da Medicina series, vol. 2. ISBN 978-85-61673-63-5. https://doi.org/10.7476/9788561673635.0041.

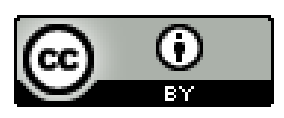

All the contents of this work, except where otherwise noted, is licensed under a Creative Commons Attribution 4.0 International license.

Todo o conteúdo deste trabalho, exceto quando houver ressalva, é publicado sob a licença Creative Commons Atribição 4.0.

Todo el contenido de esta obra, excepto donde se indique lo contrario, está bajo licencia de la licencia Creative Commons Reconocimento 4.0. 


\section{Adolpho Lutz, uma Vida Dedicada à Ciência*}

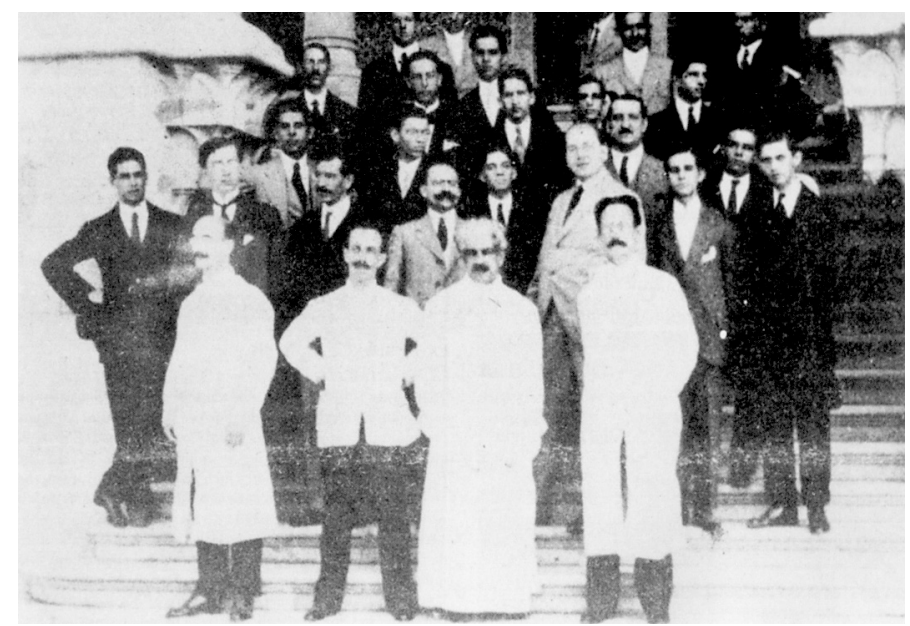

À frente, Arthur Neiva, Carlos Chagas, Oswaldo Cruz e Adolpho Lutz, no Instituto de Manguinhos (RJ), em I9I5.

W a constelação dos construtores da medicina científica no Brasil, desDescendente de família suíça, nasceu no Rio de Janeiro em i 8 de dezembro de I 855 . Seus pais haviam emigrado para o Brasil em I 849, porém, temendo as doenças epidêmicas que grassavam em nosso país, retornaram à Berna, sua cidade natal, em I 857, quando o pequeno Adolpho contava apenas dois anos. Lá ele viveu, educou-se e realizou seu curso médico, concluído em i 879 .

Em virtude de sua família haver retornado ao Brasil em i 864, fixando-se no Rio de Janeiro, Lutz também voltou em I88I. Revalidou seu diploma na Faculdade de Medicina do Rio de Janeiro e, aos 26 anos, iniciou sua brilhante trajetória que o imortalizaria na história da ciência brasileira.

Bacellar, assim como Benchimol, analisando os dados biográficos de Adolpho Lutz, dividem sua vida profissional e científica em três períodos

* Publicado em Ética Revista, 5 (3), pp. 26-27, 2007. 
(Bacellar, I963, pp. 91-I04; Benchimol, 2003, pp.I3-83). O primeiro, de I 879 a I 892, caracteriza-se por sua atividade como médico. Inicialmente, clinicou em Petrópolis no primeiro semestre de I 882 e, a seguir, transferiu-se para Limeira, no estado de São Paulo, onde permaneceu até I 885 . Com sua sólida formação médica e aguçada observação clínica, descreveu neste período uma nova doença, a acrodinia infantil.

Interessado no estudo da hanseníase, voltou à Europa para frequentar a afamada clínica dermatológica do prof. Unna, em Hamburgo, onde permaneceu por dois anos. De volta ao Brasil foi convidado em I 889 para trabalhar em um importante leprosário no Havaí, onde ficou até I 892. Nesse período, além dos estudos sobre a lepra, colheu muitos dados sobre insetos e parasitos e realizou estudos sobre o abscesso hepático e a disenteria amebiana, distinguindo-a da disenteria bacilar, o que foi confirmado anos depois por Shiga.

No Havaí, trabalhava como voluntária, nesse mesmo leprosário, uma enfermeira inglesa de nome Amy Lower, por quem Lutz se apaixonou e com quem se casou em i 891, antes de seu regresso ao Brasil. Aqui chegando, Lutz recebeu a infausta notícia do falecimento recente de sua mãe e, como seu pai já havia falecido antes, o casal decidiu fixar residência em São Paulo.

Neste mesmo ano de I892, o governo do estado de São Paulo criou o Instituto Bacteriológico, nomeando para diretor o biologista francês Félix Le Dantec e para vice-diretor Adolpho Lutz. Um ano depois, Le Dantec decidiu regressar à França e, em carta de rescisão de contrato, dizia que Lutz era mais competente do que ele, por ser ao mesmo tempo médico e naturalista, capaz de realizar trabalhos de natureza clínica e de investigação.

Começa a partir daí a segunda fase na vida de Adolpho Lutz, que vai de I 893 a I908. Nomeado diretor do instituto, em substituição a Le Dantec, revelou-se um administrador capaz e um líder empenhado na tarefa de criar a primeira escola de medicina experimental e de implantar a medicina científica no Brasil.

Apesar de seus muitos afazeres como diretor do instituto e sua preocupação em colaborar na solução dos problemas ligados à saúde pública, ainda se dedicava a pesquisas originais em diferentes setores, como a entomologia, parasitologia, protozoologia e micologia. Interessou-se particularmente pelo 
estudo dos insetos hematófagos, reunindo uma coleção de mais de dois mil exemplares, dentre os quais 36 espécies novas por ele descritas. Foi o descobridor da febre amarela silvestre, antes conhecida apenas na sua forma de doença urbana.

Quando o cólera asiático foi introduzido no Brasil, Lutz foi quem primeiro isolou das fezes de um imigrante e cultivou o bacilo, em I 893. Este achado foi posto em dúvida, até que o cólera se tornou epidêmico no país.

No final do século xix se alastrava no estado de São Paulo as chamadas "febres paulistas", cuja etiologia era desconhecida. Lutz identificou-as à febre tifoide, contrariando as opiniões que então prevaleciam entre as maiores autoridades médicas.

Em I90 i participou como voluntário das experiências de Emílio Ribas, destinadas a comprovar a descoberta feita em Cuba, da transmissão vetorial da febre amarela, deixando-se picar pelo mosquito, com risco da própria vida.

Lutz introduziu a prática da traqueostomia no tratamento de casos graves de difteria no Hospital de Isolamento, ensinando aos jovens médicos a técnica deste procedimento.

Suas pesquisas em parasitologia ampliaram notavelmente os conhecimentos sobre as parasitoses intestinais, especialmente da ancilostomíase. No campo da micologia, estudou a esporotricose e descreveu a paracoccidioidomicose, que se tornou conhecida pelo epônimo de blastomicose de Lutz ou doença de Lutz.

Lutz é também considerado pioneiro da medicina veterinária no Brasil por suas pesquisas sobre parasitos de animais, especialmente por seus estudos na ilha de Marajó sobre o mal de cadeiras, enzootia causada pelo Trypanosoma equinum (ou evansi), que acomete os equinos e outros animais, especialmente em regiões pantanosas ou alagadiças.

$\mathrm{Na}$ qualidade de diretor do Instituto Bacteriológico sofreu muitos dissabores e campanhas de desabono à sua pessoa e à instituição que dirigia, não somente por parte da imprensa leiga como de destacados médicos apegados à medicina tradicional.

Quando o instituto confirmou oficialmente a existência da epidemia de peste bubônica em Santos, em I899, houve verdadeira revolta dos comerciantes locais contra a notícia alarmista que iria prejudicar o comércio marítimo e a vida econômica da cidade. 
Desejando ir a Santos, onde já se encontrava Vital Brazil, para verificar a situação in loco, foi impedido de embarcar pelo próprio gerente da São Paulo Railways, que temia pela sua segurança.

Em I908, Lutz deixou a direção do instituto e aceitou o convite de Oswaldo Cruz para trabalhar no Instituto de Manguinhos. Impôs uma única condição: dedicar-se unicamente à pesquisa e jamais ocupar cargo ou função de natureza administrativa.

Teve início, então, o terceiro período de sua vida, que se estendeu até o seu falecimento em I940. Em Manguinhos encontrou ambiente tranquilo, apoio e condições ideais para dedicar-se inteiramente à pesquisa científica. Dedicou-se principalmente às áreas de entomologia clínica, helmintologia e zoologia, sendo particularmente relevantes seus estudos sobre o Schistosoma mansoni.

Possuidor de vasta erudição e dominando vários idiomas, seus artigos foram publicados em alemão, inglês, francês, espanhol, além de português. No necrológio de autoria de Arthur Neiva sobre a personalidade e a obra de Lutz (Neiva, I94I, pp. I-23), há menção ao total de 2I I trabalhos originais publicados por Lutz entre I 878 e 1939 .

São de Carlos Chagas as seguintes palavras sobre Adolpho Lutz quando este completou setenta anos, atingindo a idade da aposentadoria compulsória oficial estabelecida em lei:

A obra científica de Adolpho Lutz é, sem dúvida, a mais notável que haja sido realizada em nosso país, por um só pesquisador. Esse homem extraordinário, venerável e venerado, é um patrimônio da nossa raça e um dos melhores símbolos da nossa capacidade científica. Dele nos orgulhamos hoje e mais nos orgulharemos no futuro, pela projeção, no tempo, de seus feitos e de seu gênio, pela perpetuidade das criações de seu espírito iluminado (Chagas, I940, pp. I29-I36).

Lutz pertencia a numerosas sociedades científicas e recebeu em vida muitas homenagens, títulos honoríficos, medalhas e prêmios, cumprindo destacar o prêmio Einstein conferido pela Academia Brasileira de Ciências.

O casal Lutz teve dois filhos: Bertha Lutz, zoóloga do Museu Nacional, e Gualter Adolpho, que se dedicou à medicina legal. Bertha tentou várias vezes publicar o acervo científico deixado por seu pai, sem o conseguir. $\mathrm{O}$ material por ela coletado permaneceu por muitos anos no Museu Nacional 
até que foi recuperado e preservado pela Casa de Oswaldo Cruz da Fundação Oswaldo Cruz.

Sob a direção dos pesquisadores Jaime L. Benchimol e Magali Romero, e a colaboração de uma equipe de historiadores, a Casa de Oswaldo Cruz publicou em edição monumental de cinco volumes, com vários tomos, a obra completa de Adolpho Lutz, que inclui não somente sua produção científica, como sua volumosa correspondência internacional de caráter científico e outros documentos inéditos (Benchimol, Sá, Becker et al., 2003, pp. 287-409). Trata-se de uma obra de referência definitiva sobre este grande cientista.

Adolpho Lutz faleceu a 6 de outubro de I940, poucas semanas antes de completar 85 anos, em sua residência no Rio de Janeiro.

\section{Referências Bibliográficas}

Bacellar, R. C. Brazil's Contribution to Tropical Medicine and Malaria. Rio de Janeiro, Gráfica Olímpica Editora, I963.

Benchimol, J. L. “Adolpho Lutz: Um Esboço Biográfico”. História, Ciências, Saúde Manguinhos, IO, pp. I3-83, 2003.

Benchimol, J. L.; SÁ, M.R.; Becker, J. et al. "Adolpho Lutz e a História da Medicina Tropical no Brasil”. História, Ciências, Saúde - Manguinhos, Io, pp. 287-409, 2003.

Chagas, C. "Adolpho Lutz". In Ribeiro, L. Medicina no Brasil. Rio de Janeiro, Imprensa Nacional, I940.

Neiva, A. "Necrológio do Professor Adolpho Lutz". Memórias do Instituto Oswaldo Cruz, 36 (I), pp. I-23, I94I. 
